Research article

Open Access

\title{
Inhibition of insulin-like growth factor-1 receptor signaling enhances growth-inhibitory and proapoptotic effects of gefitinib (Iressa) in human breast cancer cells
}

\author{
Anne Camirand ${ }^{1}$, Mahvash Zakikhani ${ }^{1}, 2$, Fiona Young ${ }^{1}$ and Michael Pollak ${ }^{1}$ \\ 1'Lady Davis Institute for Medical Research and Department of Oncology, McGill University, Montréal, QC, Canada \\ 2Biology Department, Faculty of Science, Az-Zahra University, Vanak, Tehran, Iran \\ Corresponding author: Michael Pollak, michael.pollak@mcgill.ca
}

Received: 10 Nov 2004 Revisions requested: 20 Jan 2005 Revisions received: 23 Feb 2005 Accepted: 18 Mar 2005 Published: 12 Apr 2005

Breast Cancer Research 2005, 7:R570-R579 (DOI 10.1186/bcr1028)

This article is online at: http://breast-cancer-research.com/content/7/4/R570

(c) 2005 Camirand et al.; licensee BioMed Central Ltd.

This is an Open Access article distributed under the terms of the Creative Commons Attribution License (http://creativecommons.org/licenses/by/ 2.0), which permits unrestricted use, distribution, and reproduction in any medium, provided the original work is properly cited.

\begin{abstract}
Introduction Gefitinib (Iressa, ZD 1839, AstraZeneca) blocks the tyrosine kinase activity of the epidermal growth factor receptor (EGFR) and inhibits proliferation of several human cancer cell types including breast cancer. Phase II clinical trials with gefitinib monotherapy showed an objective response of 9 to $19 \%$ in non-small-cell lung cancer patients and less than $10 \%$ for breast cancer, and phase III results have indicated no benefit of gefitinib in combination with chemotherapy over chemotherapy alone. In order to improve the antineoplastic activity of gefitinib, we investigated the effects of blocking the signalling of the insulin-like growth factor 1 receptor (IGF-1R), a tyrosine kinase with a crucial role in malignancy that is coexpressed with EGFR in most human primary breast

Results Gefitinib and AG1024 reduced proliferation in all lines when used as single agents, and when used in combination revealed an additive-to-synergistic effect on cell growth inhibition. Flow cytometry measurements of cells stained with annexin V-propidium iodide and cells stained for caspase-3 activation indicated that adding an IGF-1R-targeting strategy to gefitinib results in higher levels of apoptosis than are achieved with gefitinib alone. Gefitinib either reduced or completely inhibited p42/p44 Erk kinase phosphorylation, depending on the cell line, while Akt phosphorylation was reduced by a combination of the two agents. Overexpression of IGF-1R in SKBR-3 cells was sufficient to cause a marked enhancement in gefitinib resistance.
\end{abstract} carcinomas.

Methods AG1024 (an inhibitor of IGF-1R) was used with gefitinib for treatment of MDA468, MDA231, SK-BR-3, and MCF-7 breast cancer lines, which express similar levels of IGF$1 \mathrm{R}$ but varying levels of EGFR. Proliferation assays, apoptosis induction studies, and Western blot analyses were conducted with cells treated with AG1024 and gefitinib as single agents and in combination.
Conclusion These results indicate that IGF-1R signaling reduces the antiproliferative effects of gefitinib in several breast cancer cell lines, and that the addition of an anti-IGF-1R strategy to gefitinib treatment may be more effective than a single-agent approach.

\section{Introduction}

The signaling activity of receptor protein tyrosine kinases (PTKs) is crucial to the control of apoptosis, differentiation, and proliferation processes; consequently, dysfunction or deregulation of these molecules can lead to uncontrolled growth and neoplastic progression. The abnormal activation of PTKs in the pathology of many cancers has called attention to these receptors as potential targets for therapeutic intervention [1-4]. Some neoplastic conditions arise from excessive activity of a single PTK, for example Bcr-Abl in chronic myeloid leukaemia [5], or c-kit or platelet-derived growth factor receptor- $\alpha$ in gastrointestinal stromal cell tumours [6], and these conditions are effectively treated using the PTK inhibitor Gleevec (Imatinib mesylate) [7]. However, most cancers have

$\overline{\mathrm{Cl}}=$ combination index; EGFR = epidermal growth factor receptor; FACS = fluorescence-activated cell sorter; FBS = fetal bovine serum; FITC = fluorescein isothiocyanate; $I_{50}=$ inhibitory concentration $50 \%$; IGF-1R= insulin like growth factor 1 receptor; PI3K= phosphatidylinositol 3-kinase; $\mathrm{PTEN}=$ phosphatase and tensin homolog; PTK = protein tyrosine kinase; VEGFR = vascular endothelial growth factor receptor. 
complex biochemical causes and may involve dysfunction of several PTKs as well as crosstalk between downstream signaling pathways. One approach to address the multiplicity problem involves cotargeting different PTKs [8-17], but for maximal efficacy, the choice of PTKs to be simultaneously blocked in any specific cancer type is crucial.

The epidermal growth factor receptor (EGFR, erbB1, or HER1) is a 170-kDa member of the erbB family of PTKs, which are transmembrane receptors with important roles in development, differentiation, proliferation, and migration [18]. The activation of EGFR by ligand binding causes dimerization and autophosphorylation of the receptor and subsequent recruitment of downstream molecules, leading to mitogenic signaling [19]. EGFR is overexpressed in a large subset of primary breast carcinomas, and EGFR ligands such as TGF- $\alpha$ and amphiregulin are found in 50 to $90 \%$ of primary breast carcinomas [20]. The co-occurrence of these sets of factors is associated with poor prognosis and resistance to hormonal therapy [21].

Several anti-EGFR molecules have been shown to cause neoplastic growth inhibition [22]. Among these, gefitinib (Iressa; AstraZeneca) is an orally active synthetic anilinoquinazoline (4(3-chloro-4-fluroanilino)-7-methoxy-6-(3-morpholinopropoxy) quinazoline) that inhibits EGFR but also has activity against erbB2 and vascular endothelial growth factor receptor 2 (VEGFR-2) at 100-fold higher than those needed for EGFR inhibition [23]. It has proved an effective inhibitor of proliferation in experimental human breast cancer cell systems, either alone or in combination with other antineoplastic agents [10,11,14,24-32]. Gefitinib as second- or third-line monotherapy in phase II trials of non-small-cell lung cancer patients provided objective tumour response rates of 9 to $19 \%$ $[22,33,34]$. A response rate of $10.8 \%$ was also seen in head and neck cancer patients [35], but phase II trials in advanced breast cancer patients showed partial response in fewer than $10 \%$ of patients [36-38]. Non-small-cell lung cancer phase III trials where gefitinib was used in combination with traditional chemotherapy (paclitaxel, gemcitabine, or cisplatin) showed no added benefit of gefitinib to patients over chemotherapy alone $[39,40]$. The acceptable safety profile of gefitinib was, however, confirmed by these studies, and the results motivate studies to determine if PTK cotargeting might improve the efficacy of the drug.

A potential cotarget receptor in breast cancer is the insulin-like growth factor 1 receptor (IGF-1R). In its mature form, IGF-1R is a heterotetrameric receptor (two extracellular $125-\mathrm{kDa} \alpha$ chains and two transmembrane $95-\mathrm{kDa} \beta$ chains) that autophosphorylates after ligand binding and activates several downstream signaling routes, including the phosphatidylinositol 3-kinase (PI3K) and mitogen-activated protein kinase (MAPK) pathways. Signaling through IGF-1R stimulates proliferation, promotes angiogenesis and metastasis, and inhibits apoptosis [41-45]. There is now abundant evidence indicating that signaling through the IGF-1R pathway is important in many cancers, including breast cancer [4,42,46-49], and recent preclinical work has shown that IGF-1R could be used as a successful cotarget with EGFR in primary human glioblastoma cells $[13,50]$, with c-kit in small-cell lung cancer $[15,17]$, and with HER2/erbB2 in breast cancer cells $[12,16]$. AG1024 (3-bromo-5-t-butyl-4-hydroxy-benzylidenemalonitrile) is a synthetic tyrphostin that inhibits ligand-stimulated IGF-1R autophosphorylation in intact cells, with an inhibitory concentration $50 \%\left(\mathrm{IC}_{50}\right)$ of $7 \mu \mathrm{M}$ and can affect the insulin receptor at 9- to 10-fold higher concentrations $\left(\mathrm{IC}_{50} 57 \mu \mathrm{M}\right)$ [51]. Tyrphostins bind to the active site of receptors and modify its conformation to prevent the substrate and ATP from binding [51]. Through its anti-IGF-1R activity, AG1024 inhibits cell proliferation and induces apoptosis in several cell systems, including non-smallcell lung cancer [52], small-cell lung cancer [17], melanoma [53], and breast cancer [54].

In this study, AG1024 and gefitinib were used to cotarget IGF$1 \mathrm{R}$ and EGFR activity in several human breast cancer cell lines that express IGF-1R similarly but present different levels of EGFR. We show that combination treatment causes additivity or synergy in growth inhibition and apoptosis induction, and we speculate that adding an anti-IGF-1R strategy to gefitinib treatment may be more effective than single-agent gefitinib therapy.

\section{Materials and methods Chemicals and drugs}

Gefitinib (ZD 1839, Iressa) was a gift from AstraZeneca (Macclesfield, UK). AG1024 was purchased from CalbiochemEMD Biosciences (La Jolla, CA, USA).

\section{Cell lines and proliferation assays}

Breast cancer cell lines MCF-7, MDA468, MDA231, and SKBR-3 were obtained from ATCC (Manassas, VA, USA). Cells were cultured at $37^{\circ} \mathrm{C}$ with $5 \% \mathrm{CO}_{2}$ in RPMl 1640 (MCF-7) or McCoy medium (all other cell lines) with 10\% fetal bovine serum (FBS) (InVitrogen, Gaithersburg, MD, USA), except in growth inhibition assays, where the FBS supplement was reduced to $1 \%$. Cell proliferation was measured with the Alamar Blue dye reduction method (Biosource International, Camarillo, CA, USA). Growth tests were conducted with $10^{4}$ cells/well in $200 \mu \mathrm{l}$ media in 96-well plates, and three replicates per dose combination were used for each experiment. Experiments shown here are representative of three repeats. Stock solutions of tyrphostin AG1024 and gefitinib were made in dimethyl sulfoxide to $10 \mathrm{mM}$, stored at $-20^{\circ} \mathrm{C}$, and diluted in medium containing $1 \%$ FBS just before use. The concentration of dimethyl sulfoxide in the final culture was kept below $0.2 \%(\mathrm{v} / \mathrm{v})$. All procedures involving tyrphostins were conducted in low light intensity. 
MDA468
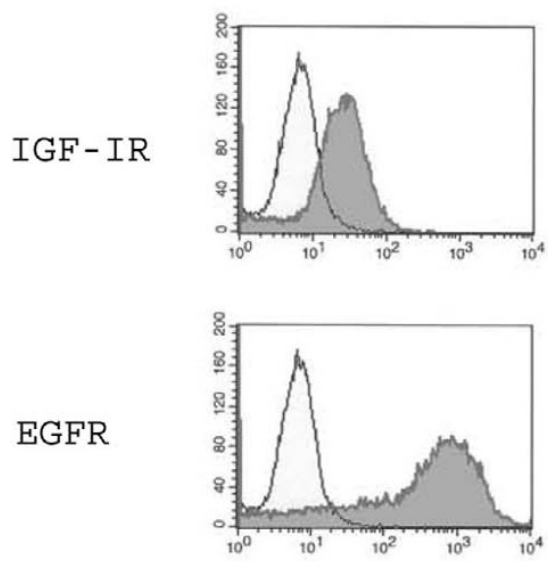

$\mathrm{MCF}-7$
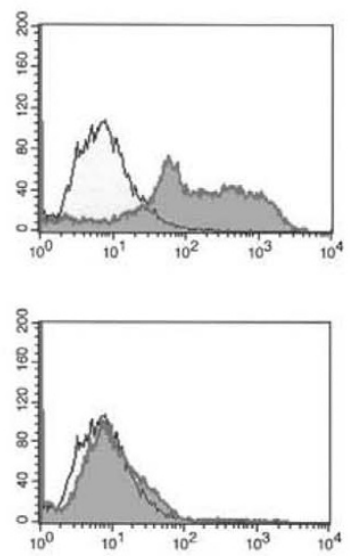

MDA231
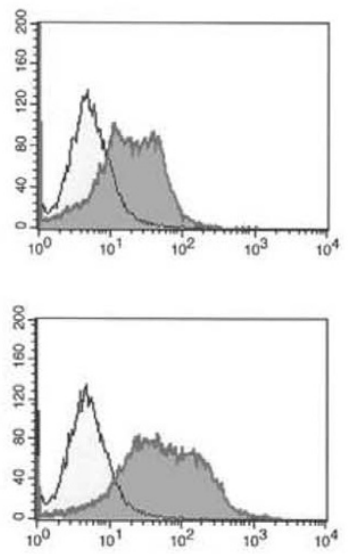

$\mathrm{SK}-\mathrm{BR}-3$
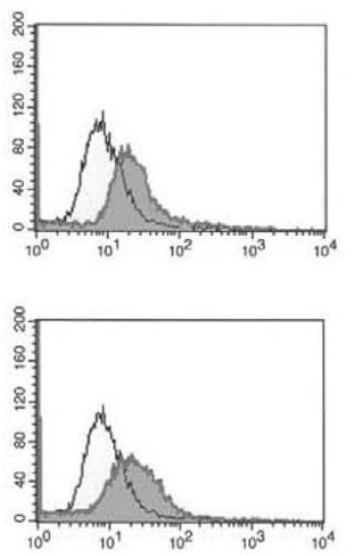

Surface expression of IGF-1R and EGFR in human breast cancer cell lines. Untreated cells were stained with phycoerythrin-conjugated anti-IGF-1R (insulin like growth factor-1 receptor) or with fluorescein-isothiocyanate-conjugated anti-EGFR (anti-epidermal growth factor receptor) antibody. Shaded peaks show flow cytometry analysis of the number of insulin-like growth factor 1 (top row) and epidermal growth factor (bottom row) receptors on the surface of MDA468, MCF-7, MDA231, and SK-BR-3 human breast cancer cells. Outlined peak represents isotype control (normal mouse $\left.\lg G_{1}\right)$. Counts indicate number of events.

\section{Flow cytometry for receptors}

Medium was removed from breast cancer cells growing in monolayers, and cells were collected by scraping in $1 \mathrm{ml} 4^{\circ} \mathrm{C}$ FACS (fluorescence-activated cell sorter) buffer (3\% fetal bovine serum, $0.02 \% \mathrm{NaN}_{3}$ in PBS). Cells were centrifuged and washed in FACS buffer; approximately $10^{6}$ cells were stained with phycoerythrin-conjugated anti-IGF-1R (BD Pharmingen, San Diego, CA, USA), or with fluorescein-isothiocyanate-conjugated (FITC-conjugated) anti-EGFR antibody (Santa Cruz Biotechnology, Santa Cruz, CA, USA) for $30 \mathrm{~min}$ at $4^{\circ} \mathrm{C}$ in the dark, washed twice in FACS, and resuspended in the same buffer. Analysis was conducted for 20,000 cells using a FACSCalibur flow cytometer (BD Biosciences, Burlington, MA, USA) with CellQuest software (BD Biosciences Immunocytometry Systems, Franklin Lakes, NJ, USA). Normal mouse $\operatorname{lgG}_{1}$ (Santa Cruz Biotechnology) was used for isotype determination. All tests were conducted in duplicate and the experiments shown here are representative of two repeats.

\section{Flow cytometry for apoptosis induction}

Growth medium was removed from breast cancer cells growing in monolayers; adherent cells were briefly trypsinized, detached, combined with floating cells from the original growth medium, centrifuged, and washed twice with PBS. Approximately $10^{6}$ cells were stained for 30 min with annexinV-FITC and propidium iodide using the ApoTarget kit (Biosource International). Analysis was conducted on a FACSCalibur flow cytometer using CellQuest software (see receptor section, above). For quantification of caspase-3 activation, cells (approximately $0.5 \times 10^{6}$ ) were obtained as for testing with annexin $V$ and propidium iodide, but were washed in media, resuspended in $150 \mu$ media containing 10\% FBS and $0.5 \mu$ l Red-DEVD-FMK (Caspase-3 detection kit, Calbiochem-EMD Biosciences), and incubated for $30 \mathrm{~min}$ at $37^{\circ} \mathrm{C}$ in a cell-culture incubator with $5 \% \mathrm{CO}_{2}$. The stained cells were centrifuged, washed twice with the wash buffer provided in the kit, resuspended in $500 \mu \mathrm{l}$ of the same buffer, and analyzed for fluorescence on a FACSCalibur flow cytometer using CelIQuest software. All apoptosis tests were conducted in duplicate and results shown are representative of three experiments.

\section{Western blotting and immunoprecipitation}

Cells growing in monolayers in $10-\mathrm{cm}$ culture plates were treated with various doses of AG1024, gefitinib, or vehicle for 24 or 72 hours, then lysed in nondenaturing buffer (1\% Nonidet NP-40, $20 \mathrm{mM}$ TrisCl pH 8.0; $0.5 \mathrm{mM}$ sodium orthovanadate, $\mathrm{pH}$ 9.0; and proteinase inhibitors (Roche, Mannheim, Germany)), and particulate material was removed by centrifugation at $4^{\circ} \mathrm{C}$. Samples $(50 \mu \mathrm{g})$ of the supernatant were separated on $10 \%$ or $15 \%$ polyacrylamide gels. After transfer to TransBlot nitrocellulose membranes (BioRad, Hercules, CA, USA), the proteins were reacted overnight with the following primary antibodies at 1:1,000 dilution: anti-Akt, anti-phosphoAkt (Ser473), anti-Erk1/Erk2 (p44/42) anti-phospho-Erk1/ Erk2 (Thr202/Tyr204), and anti-EGFR (Cell Signalling Technologies, Beverly, MA, USA). Anti-phospho-EGFR (Tyr1173) was from Upstate (Charlottesville, VA, USA). Blots were then reacted for 1 hour with 1:2,000 horseradish-peroxidase-conjugated antirabbit immunoglobulin G (Pharmacia-Amersham, Piscataway, NJ, USA). Tubulin 1:200 (Santa Cruz Biotechnology) and antimouse immunoglobulin G (Pharmacia-Amer- 
(a)

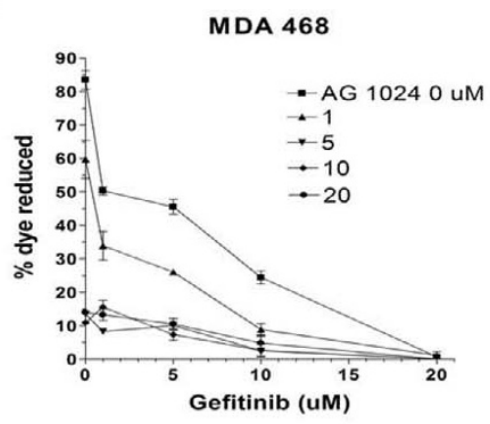

MDA 231

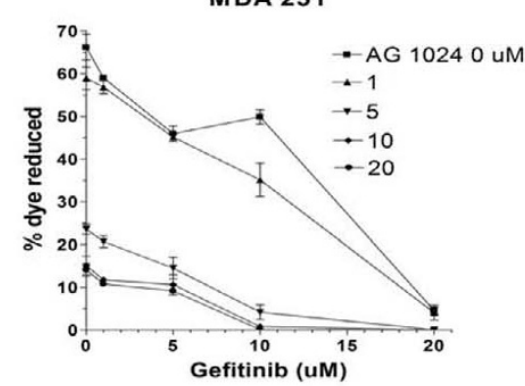

MCF-7

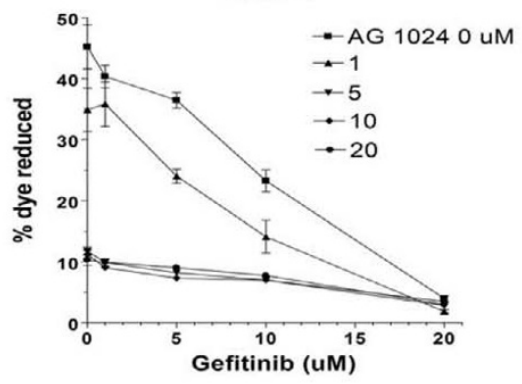

SK-BR-3

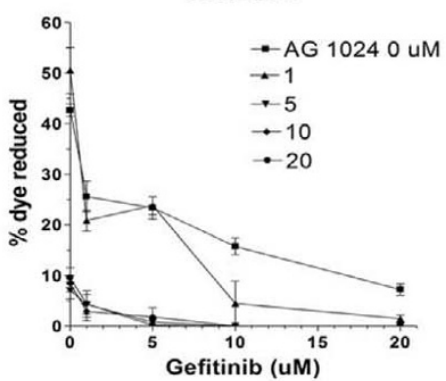

(b)

\begin{tabular}{lllllc} 
& AG 1024 & \multicolumn{2}{l}{ Gefitinib } & CI \\
MDA468 & 0.6 & uM & 5.0 & uM & 0.80 \\
& 1.25 & uM & 1.0 & uM & 0.49 \\
MCF-7 & 1.4 & uM & 7.5 & uM & 1.10 \\
& 1.8 & uM & 5.0 & uM & 1.06 \\
MDA231 & 3.2 & uM & 5.0 & uM & 1.14 \\
& 4.0 & uM & 1.0 & uM & 0.97 \\
SK-BR-3 & 0.6 & uM & 5.0 & uM & 1.01 \\
& 1.8 & uM & 1.0 & uM & 0.87
\end{tabular}

Inhibition of breast cancer cell growth by AG1024 and gefitinib singly and in combination. (a) Cells in exponential stages of growth were exposed to increasing concentrations of inhibitors for 72 hours in media containing $1 \%$ fetal bovine serum. Triplicates were used for each dose combination for each experiment. (b) Proliferation combination index $(\mathrm{Cl})$ values were calculated using the classic isobologram equation [55] and indicate synergy $(\mathrm{Cl}<1)$ or additivity $(\mathrm{Cl}$ approximately 1$)$.

sham) were used to check evenness of loading. Membranes were reacted with enhanced chemiluminescence $(E C L)$ reagents (Pharmacia-Amersham) and exposed to X-OMAT LS film (Kodak, Rochester, NJ, USA). For immunoprecipitation, $500-\mu \mathrm{g}$ samples of soluble protein in a final volume of $500 \mu \mathrm{l}$ were incubated with $10 \mu \mathrm{l}$ antiphosphotyrosine monoclonal antibody (BD Pharmingen, Mississauga, ON, Canada) with rotation at $4^{\circ} \mathrm{C}$ overnight. A mixture $(20 \mu \mathrm{l})$ of protein $\mathrm{A}$ and $\mathrm{G}+$ Sepharose beads (Santa Cruz Biotechnology) was then added, and the samples were rotated at $4^{\circ} \mathrm{C}$ for 1 hour. Beads were collected by centrifugation, washed once with lysis buffer, heated for $5 \mathrm{~min}$ at $95^{\circ} \mathrm{C}$ in SDS-PAGE loading buffer, and separated by electrophoresis. Membranes after transfer were reacted with an anti-IGF-1R $\beta$-subunit antibody (Santa
Cruz Biotechnology) and processed as above for enhanced chemiluminescence detection. Western blot analyses were repeated twice.

\section{Statistical analysis}

Statistical validity was evaluated using Student's $t$-test or the Student Newmany-Keuls test for multiple pairwise comparisons of means with Statistical Analysis System software, version 8 (SAS Institute, Cary, NC, USA), with $P$ values $\leq 0.05$ considered significant. 
(a)

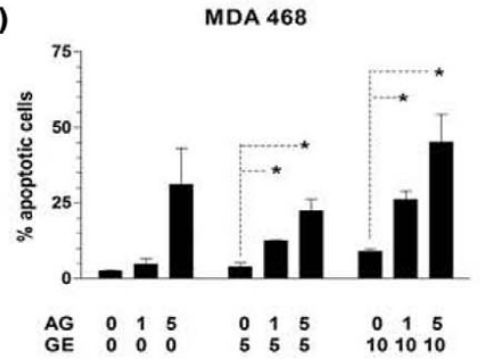

MDA 231

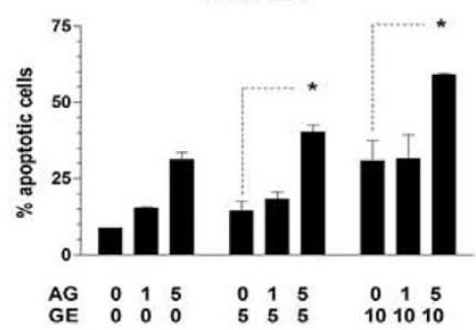

(b)

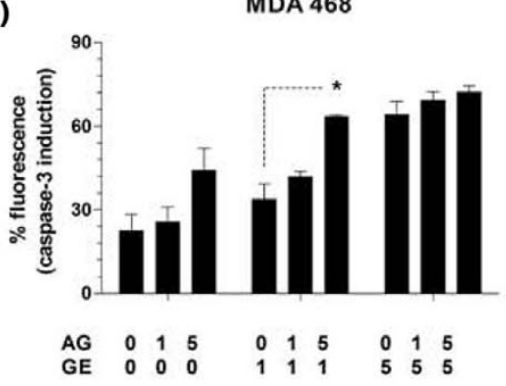

MDA 231

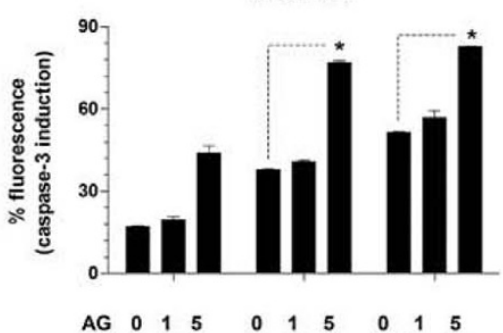

MCF-7

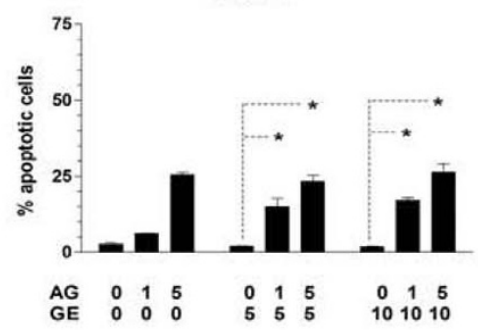

SK-BR-3

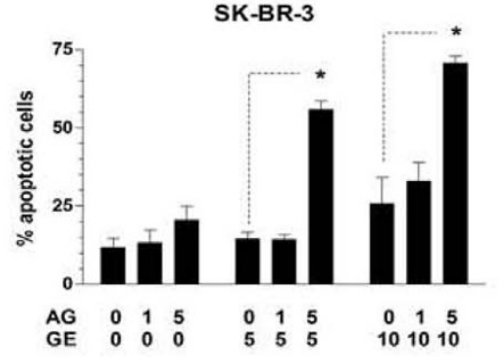

$\begin{array}{lllllllccc}\mathrm{AG} & 0 & 1 & 5 & 0 & 1 & 5 & 0 & 1 & 5 \\ \mathrm{GE} & 0 & 0 & 0 & 5 & 5 & 5 & 10 & 10 & 10\end{array}$

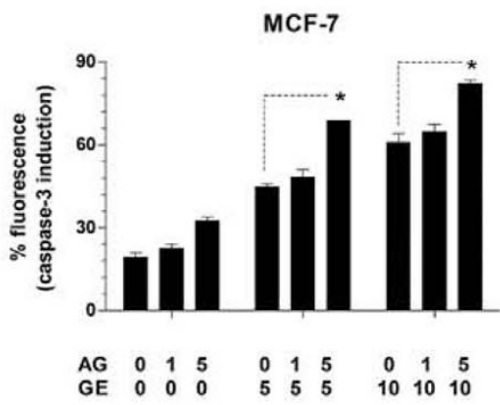

SK-BR-3

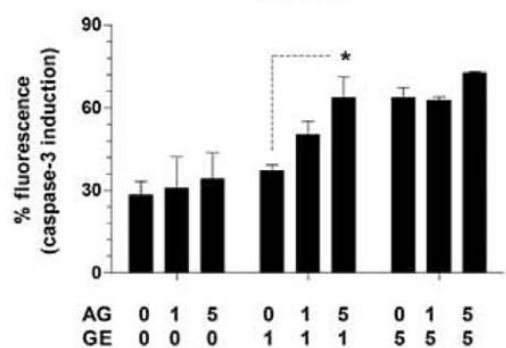

Treatment with AG1024 enhances apoptotic effects of gefitinib. (a) Flow cytometric analysis of apoptosis in cells stained with annexin V and propidium iodide after 72-hour treatment of breast cancer cells with AG1024 (AG), gefitinib (GE), or both. (b) Flow cytometric analysis of caspase-3 induction by Red-DEVD-FMK fluorescence after 24-hour treatment of cells with AG1024, gefitinib, or both. Addition of AG1024 to gefitinib treatment significantly enhanced apoptotic induction over levels achieved by gefitinib alone. Values on horizontal axes are concentrations $(\mu \mathrm{M}) .{ }^{\star} P<$ 0.05 . 


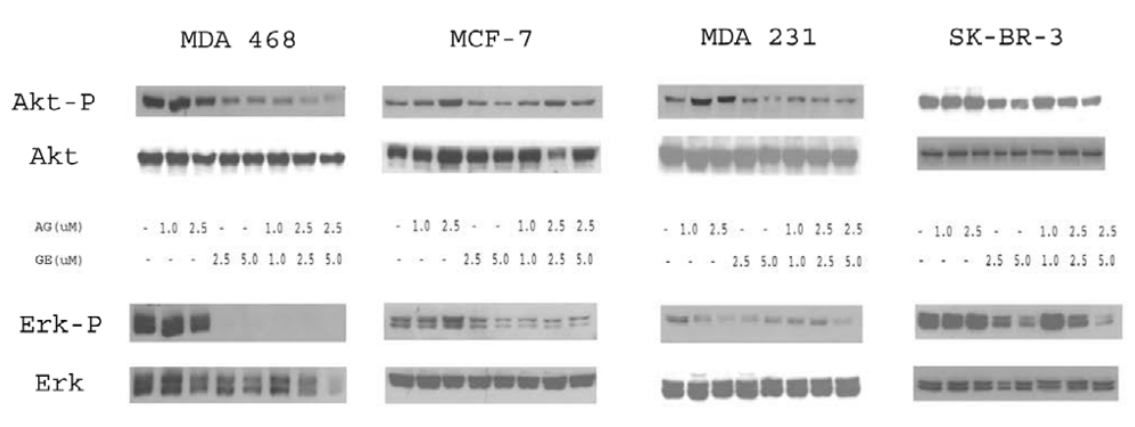

Effect of treatment on Erk and Akt kinases phosphorylation and protein levels. Western blot analysis showing phosphorylation (P) (top) and protein (bottom) levels of Akt and p44/p42 Erk kinases in cells treated for 24 hours with AG1024 (AG), gefitinib (GE), or both.

\section{Results \\ Surface expression of IGF-1R and EGFR in breast cancer cell lines}

The breast cancer cell lines tested exhibit similar surface expression of the IGF-1 receptor, but the number of EGF receptors varied considerably, with MDA468 cells showing very high expression, MDA231 intermediate levels, SK-BR-3 low expression, and MCF-7 no significant presence of EGFR (Fig. 1).

\section{Inhibition of IGF-1R signaling enhances the effect of gefitinib on the proliferation of breast cancer cell lines} In the culture conditions used here, proliferation $I_{50}$ values (means \pm standard deviations) for AG1024 were $3.5 \mu \mathrm{M} \pm 0.4$ for MDA468; $3.5 \mu \mathrm{M} \pm 0.5$ for MCF-7; $4.5 \mu \mathrm{M} \pm 0.4$ for MDA231; and $2.5 \pm 0.4$ for SK-BR-3 cells. The respective $\mathrm{IC}_{50}$ values for gefitinib were $8.0 \mu \mathrm{M} \pm 1.0 ; 9.2 \mu \mathrm{M} \pm 2.3 ; 11.5$ $\mu \mathrm{M} \pm 3.0$; and $6.5 \mu \mathrm{M} \pm 1.5$.

The use of treatments combining AG1024 and gefitinib revealed that the cotargeting approach achieved a greater growth inhibition (Fig. 2a). Combination index (Cl) values calculated according to the classic isobologram equation [55] evaluate the interactions between agents as additive $(\mathrm{Cl}$ approximately 1$)$, antagonistic $(\mathrm{Cl}>1)$, or synergistic $(\mathrm{Cl}<1)$. The results (Fig. 2b) indicate synergy (for MDA468) or additivity (other cell lines) of interaction between AG1024 and gefitinib.

\section{Adding an anti-IGF-1R strategy to gefitinib treatment increases levels of apoptosis}

Flow cytometric analyses of breast cancer cells treated with AG1024, gefitinib, or both, and stained with annexinV and propidium iodide (cells treated for 3 days) or with red-DEVDFMK for caspase-3 activation (cells treated for 1 day) are shown in Fig. 3a,b. In all cell lines, and for both methods of detecting apoptosis, conditions were found where addition of AG1024 significantly increased apoptosis levels over those seen with gefitinib alone.
Effect of treatment with AG1024 or gefitinib on protein and phosphorylation levels of Akt and p44/p42 Erk kinases

After 24 hours of treatment, gefitinib decreased the levels of Erk phosphorylation in most cell lines, and completely eliminated Erk phosphorylation in MDA468 (Fig. 4). In contrast, the phosphorylation levels of Akt were reduced by the combination of the two agents. Erk and Akt protein levels were not affected by the 24-hour treatments. Tubulin levels confirmed equal loading (not shown).

\section{Overexpression of IGF-1R greatly reduces sensitivity to gefitinib}

SK-BR-3 cells transfected to overexpress the IGF-1 receptor (SK-BR-3-IR) [12] were tested for sensitivity to gefitinib. Figure 5 a illustrates the high IGF-1R expression levels observed by flow cytometry in SK-BR-3-IR cells compared with the levels in the SK-BR-3 parental line shown in Fig. 1. Increased expression of IGF-1R caused a very marked enhancement in resistance to the growth-inhibitory effects of gefitinib (Fig. 5b).

\section{Effect of treatment with AG1024 or gefitinib on tyrosine phosphorylation of IGF-1R and EGFR}

An example of the effect of AG1024, gefitinib, or both (24hour treatment) on the phosphorylation levels of IGF-1 and EGF receptors in 1\% serum conditions is illustrated in Fig. 6. In MCF-7 cells (left), AG1024 at $2.5 \mu \mathrm{M}$ eliminated phosphorylation of IGF-1R, while gefitinib did not affect the phosphorylation state of IGF-1R. EGFR phosphorylation levels were decreased by gefitinib, but only slightly affected by AG1024 treatment (MDA468 cells, Fig. 6, right). Protein levels for both receptors were unaffected by treatment in the conditions used here.

\section{Discussion}

Several reports have suggested that cotargeting protein tyrosine kinases results in substantial enhancement of growth inhibition [8-17]. In the present study, the choice of the IGF-1 receptor as cotarget is based on the knowledge that this receptor drives important cell survival pathways [41-45] and 
Figure 5

(a)

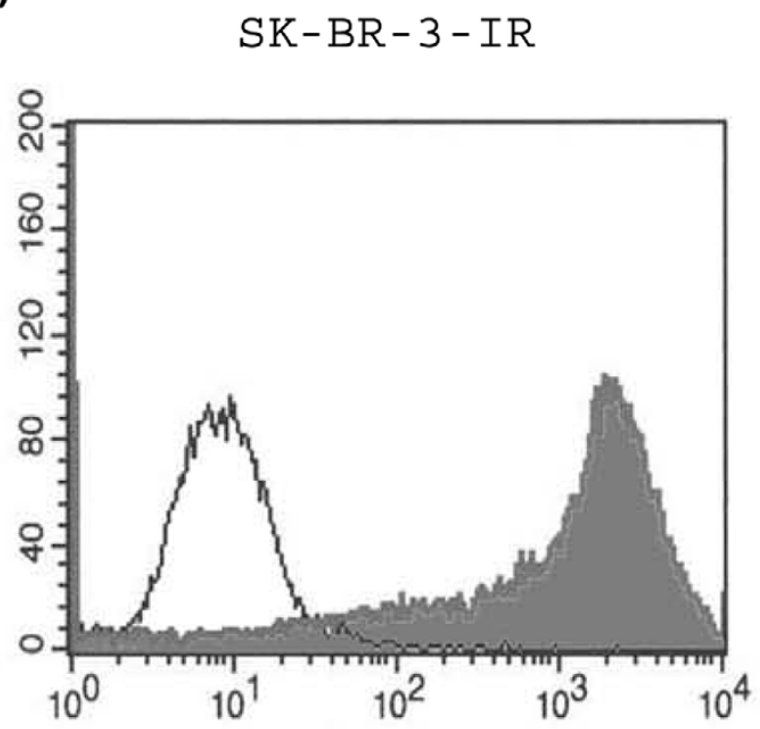

(b)

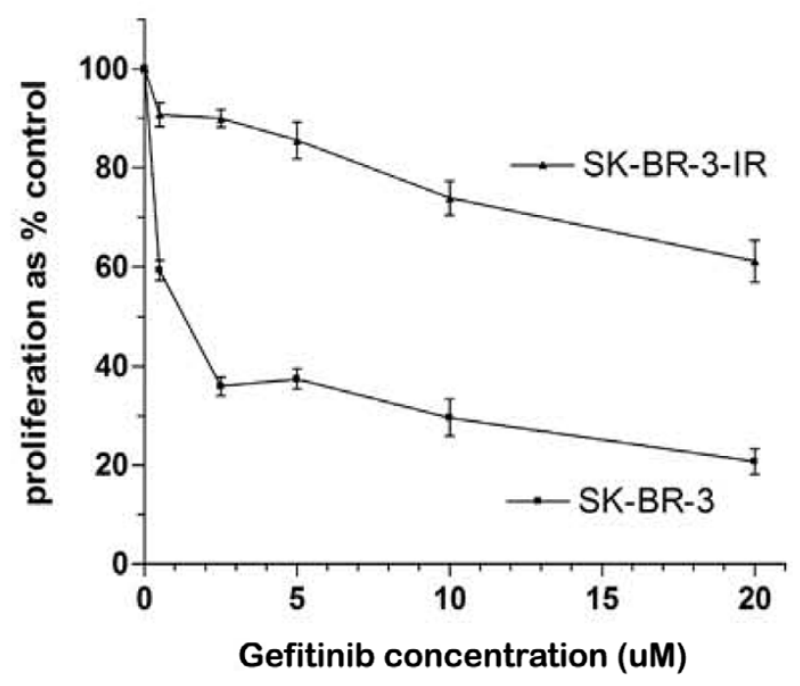

Overexpression of IGF-1R results in enhanced resistance to gefitinib antiproliferation activity. (a) Flow cytometry estimation of surface expression levels of epidermal growth factor 1 receptor (IGF-1R) (shaded peak) in the SK-BR-3-IR line, which differs from its parental line, SK-BR-3, only by the transfected IGF-1R gene [12]. Outlined peak is normal mouse $\operatorname{lgG}_{1}$ isotype. Counts indicate number of events. (b) Effect of a 72-hour treatment with gefitinib alone on the proliferation of SK-BR-3 and SK-BR-3-IR cells. Triplicates were used for each dose.

that reduction of its antiapoptotic effects increases the efficacy of treatments targeting several other neoplasia-related PTKs [12,13,15-17]. The results presented here show the effects of adding an anti-IGF-1R strategy to gefitinib treatment in human breast cancer cell lines chosen for their similar expression of IGF-1R but their different EGFR levels (Fig. 1).

Gefitinib and AG1024 used as single agents show antiproliferative activity on all cell lines tested, and their combination produces an additive-to-synergistic enhancement of growth inhibition (Fig. 2a,b). The mechanism of action on cancer cells of EGFR blockers such as AG 1478, mAb225, and gefitinib is generally cytostatic and proceeds via a G0/G1 arrest [56]. Most breast cancer cells are growth-arrested by gefitinib, but only a subset shows induction of apoptosis (cytotoxic effect) [31], and high doses of the drug are needed to induce apoptosis in normal mammary epithelial cells and primary cultures of mammary carcinoma cells [24]. Blocking the antiapoptotic IGF-1R pathway with AG1024 improves apoptosis induction over the level due to treatment with gefitinib alone (Fig. 3). All the cell lines tested exhibited this effect, regardless of the levels of expression of EGFR. In fact, the growth-inhibitory effect of gefitinib has been reported to be independent of the levels of expression of EGFR in human breast cancer cells [10,2426,31] and other cancer cell lines [57]. As the EGFR expression level is not a good predictor of gefitinib sensitivity [58], EGFR expression status in tumours cannot be used to exclude patients from gefitinib trials [59]. It has been shown that the presence of somatic mutations in the EGFR gene in lung cancer samples correlates with sensitivity to gefitinib $[60,61]$. However, even in the absence of detectable EGFR (as in MCF-7 cells: our results, Fig. 1, and [10]), gefitinib and AG1024 still have additive capability, raising the possiblity of a non-EGFR-specific gefitinib effect that can be enhanced by the anti-IGF-1R agent.

Western blot analysis (Fig. 4) showed that after a 24-hour treatment, gefitinib affects phosphorylation levels of p44/p42 Erk and Akt kinases, but that combination treatment with the anti-IGF-1R agent causes a further reduction in levels of Akt phosphorylation. The effect is particularly visible for MDA468 cells, which probably reflects the fact that these cells show a synergistic rather than additive growth reduction pattern. Interestingly, MDA468 cells (PTEN-null) (phosphatase-and-tensinhomolog-null) have been reported to show a relative resistance to gefitinib that can be reversed through the use of the PI3K inhibitor LY294002 [62] or PTEN reconstitution [30], pointing to a crucial role for receptors that signal through the PI3K cascade, such as IGF-1R. MDA468 cells are also the most sensitive to gefitinib inhibition of Erk phosphorylation. In longer treatments (not shown), the levels of protein expression for Akt and Erk are decreased by AG1024 or by the combination of agents. AG1024 treatment has been reported to decrease the expression of several proteins known as regulators of apoptosis and the cell cycle [53,54], and the inhibitor may therefore also provide a longer-term inhibitory effect by mechanisms involving protein degradation. 


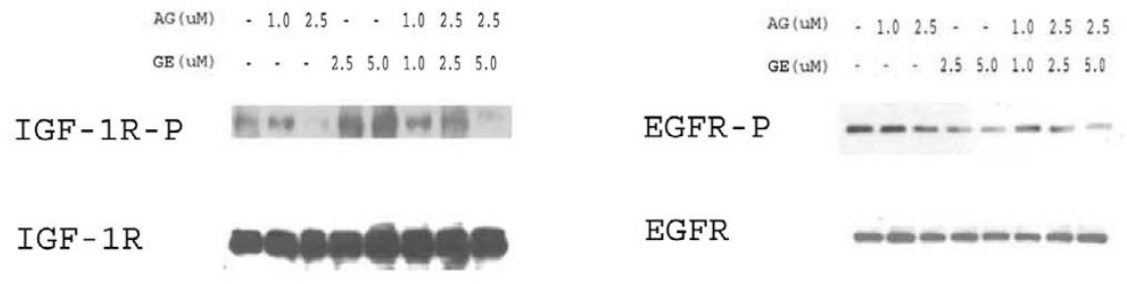

Single agent treatment effect on tyrosine phosphorylation $(P$; top) and protein expression of receptors. Western blot showing phosphorylation $(P$, top) and receptor protein levels (bottom). MCF-7 cells were used for detection of phosphorylation of the insulin like growth factor 1 receptor (IGF$1 \mathrm{R})$ and MDA468 cells, for phosphorylation analysis of the epidermal growth factor receptor (EGFR). AG, AG1024; GE, gefitinib.

An important point, illustrated in Fig. 5, is that overexpression of the IGF-1 receptor results in increased resistance to gefitinib. This observation implies that one way in which breast cancer cells resist gefitinib is through the signaling activity of IGF1R. Since gefitinib does not affect phosphorylation of the IGF1 receptor (Fig. 6 and [63]), our results suggest that the antiapoptotic pathways driven by IGF-1 signalling should be targeted in order to optimize the antineoplastic effects of gefitinib. While our model system involves increased IGF-1R activity due to receptor overexpression, it must be noted that increased IGF-1R signaling in clinical breast cancer might also arise from mechanisms involving abnormally high IGF-2 expression or from derangements in IGF-binding protein physiology [42].

The findings described here suggest that the antineoplastic effects of gefitinib may be significantly underestimated if examined only under conditions in which IGF-IR is fully functional. Several anti-IGF-1R compounds are now being developed for clinical evaluation [64-67], and it should soon be feasible to conduct trials to test the hypothesis that the efficacy of gefitinib treatments is enhanced by IGF-1R targeting. The data presented here support further research into breast cancer therapeutic strategies combining gefitinib with anti-IGF-1R agents.

\section{Conclusion}

In several human breast cancer cell lines, addition of the IGF$1 \mathrm{R}$ inhibitor AG1024 to gefitinib reduced cell proliferation in an additive or synergistic fashion and enhanced the induction of apoptosis over levels achieved by gefitinib alone. This effect was independent of levels of expression of the EGF receptor. Overexpression of IGF-1R in SK-BR-3 cells was sufficient to cause a marked enhancement in gefitinib resistance. IGF-1R signaling can therefore limit the antiproliferative effects of gefitinib in vitro, and we speculate that for a subset of human breast cancers, adding an anti-IGF-1R strategy to gefitinib treatment may be more effective than a single-agent approach.

\section{Competing interests}

The author(s) declare that they have no competing interests.

\section{Authors' contributions}

Anne Camirand: study design, data collection, statistical analysis, data interpretation, manuscript preparation, literature search and funds collection. Mahvash Zakikhani: data collection, statistical analysis, data interpretation, manuscript preparation, literature search. Fiona Young: data collection. Michael Pollak: study design, funds collection.

All authors read and approved the final manuscript.

\section{Acknowledgements}

This work was supported by a grant to MP and AC from the Susan G Komen Foundation for Breast Cancer Research. Gefitinib was a gift from AstraZeneca (Macclesfield, UK).

\section{References}

1. Arteaga CL, Moulder SL, Yakes FM: HER (erbB) tyrosine kinase inhibitors in the treatment of breast cancer. Semin Oncol 2002, 29:4-10.

2. Shawver LK, Slamon D, Ullrich A: Smart drugs: Tyrosine kinase inhibitors in cancer therapy. Cancer Cell 2002, 1:117-123.

3. Dancey J, Sausville EA: Issues and progress with protein kinase inhibitors for cancer treatment. Nat Rev Drug Discov 2003, 2:296-313.

4. Surmacz E: Growth factor receptors as therapeutic targets: strategies to inhibit the insulin-like growth factor-I receptor. Oncogene 2003, 22:6589-6597.

5. Melo JV: The diversity of BCR-ABL fusion proteins and their relationship to leukemia phenotype. Blood 1996 88:2375-2384.

6. Heinrich MC, Corless CL, Duensing A, McGreevey L, Chen C-J, Joseph N, Singer S, Griffith DJ, Haley A, Town A, et al:: PDGFRA activating mutations in gastrointestinal stromal tumors. Science 2003, 299:708-710.

7. Druker BL, Talpaz M, Resta DJ, Peng B, Buchdunger E, Ford JM, Lydon NB, Kantardjian H, Capdeville R, Ohno-Jones S, et al:: Efficacy and safety of a specific inhibitor of the Bcr-Abl tyrosine kinase in chronic myeloid leukemia. New Engl J Med 2001, 344:1031-1037.

8. Wu X, Fan Z, Masui H, Rosen N, Mendelsohn J: Apoptosis induced by an anti-EGFR monoclonal antibody in human colorectal carcinoma cell line and its delay by insulin. J Clin Invest 1995, 95:1897-1905.

9. Ye D, Mendelsohn J, Fan Z: Augmentation of a humanized antiHER2 mAb 4D5 induced growth inhibition by a human-mouse chimeric anti-EGF receptor mAb C225. Oncogene 1999, 18:731-738.

10. Moasser MM, Basso A, Averbuch SD, Rosen N: The tyrosine kinase inhibitor ZD1839 ("Iressa") inhibits HER2-driven signaling and suppresses the growth of HER2-overexpressing tumor cells. Cancer Res 2001, 61:7184-7188. 
11. Moulder SL, Yakes FM, Muthuswamy SK, Bianco R, Simpson JF, Arteaga CL: Epidermal growth factor receptor (HER1) tyrosine kinase inhibitor ZD1839 (Iressa) inhibits HER2/neu (erbB2)overexpressing breast cancer cells in vitro and in vivo. Cancer Res 2001, 61:8887-8895.

12. Lu Y, Zi X, Zhao Y, Mascarenhas D, Pollak M: Insulin-like growth factor-I receptor signaling and resistance to trastuzumab (Herceptin). J Natl Cancer Inst 2001, 93:1852-1857.

13. Chakravarti A, Loeffler JS, Dyson NJ: Insulin-like growth factor receptor I mediates resistance to anti-epidermal growth factor receptor therapy in primary human glioblastoma cells through continued activation of phosphoinositide 3-kinase signaling. Cancer Res 2002, 62:200-207.

14. Normanno N, Campiglio M, De LA, Somenzi G, Maiello M, Ciardiello F, Gianni L, Salomon DS, Menard S: Cooperative inhibitory effect of ZD1839 (Iressa) in combination with trastuzumab (Herceptin) on human breast cancer cell growth. Ann Oncol 2002, 13:65-72.

15. Warshamana-Grene GS, Litz J, Buchdunger E, Hofmann F, Garcia-Echeverria C, Krystal GW: The insulin-like growth factor-I (IGF-I) receptor kinase inhibitor NVP-ADW742, in combination with STI571, delineates a spectrum of dependence of small cell lung cancer on IGF-I and stem cell factor signalling. Mol Cancer Ther 2004, 3:527-535.

16. Camirand $A$, Lu $Y$, Pollak M: Co-targeting HER2/ErbB2 and insulin-like growth factor-1 receptors causes synergistic inhibition of growth in HER2-overexpressing breast cancer cells. Med Sci Monit 2002, 8:BR521-BR526.

17. Camirand A, Pollak M: Co-targeting IGF-1R and c-kit: synergistic inhibition of proliferation and induction of apoptosis in $\mathrm{H}$ 209 small cell lung cancer cells. $\mathrm{Br} J$ Cancer 2004, 90:1825-1829.

18. Rusch V, Mendelsohn J, Dmitrovsky E: The epidermal growth factor receptor and its ligands as therapeutic targets in human tumors. Cytokine Growth Factor Rev 1996, 7:133-141.

19. Yarden $Y$ : The EGFR family and its ligands in human cancer: signalling mechanisms and therapeutics opportunities. Eur $J$ Cancer 2001, 37:S3-S8.

20. Salomon DS, Brandt R, Ciardiello F, Normanno N: Epidermal growth factor-related peptides and their receptors in human malignancies. Crit Rev Oncol Hematol 1995, 19:183-232.

21. Woodburn JR: The epidermal growth factor receptor and its inhibition in cancer therapy. Pharmacol Ther 1999, 82:241-250.

22. Blackledge $\mathrm{G}$, Averbuch S: Gefitinib ('Iressa', ZD 1839) and new epidermal growth factor receptor inhibitors. Br J Cancer 2004, 90:566-572.

23. Ranson M: ZD1839 (Iressa): for more than just non-small cell lung cancer. Oncologist 2002, 7:16-24.

24. Ciardiello $F$, Caputo $R$, Bianco R, Damiano V, Pomatico G, De Placido S, Bianco AR, Tortora G: Antitumor effect and potentiation of cytotoxic drugs activity in human cancer cells by ZD1839 (Iressa), an epidermal growth factor receptor-selective tyrosine kinase inhibitor. Clin Cancer Res 2000, 6:2053-2063.

25. Ciardiello F, Caputo R, Bianco R, Damiano V, Fontanini G, Cuccato S, De Placido S, Raffaele Bianco A, Tortora G: Inhibition of growth factor production and angiogenesis in human cancer cells by ZD1839 (Iressa)', a selective epidermal growth factor receptor tyrosine kinase inhibitor. Clinical Cancer Research 2001, 7:1459-1465

26. Anderson NG, Ahmad T, Chan K, Dobson R, Bundred NJ: ZD1839 (Iressa), a novel epidermal growth factor receptor (EGFR) tyrosine kinase inhibitor, potently inhibits the growth of EGFRpositive cancer cell lines with or without erbB2 overexpression. Int J Cancer 2001, 94:774-782.

27. Nicholson RI, Hutcheson IR, Harper ME, Knowlden JM, Barrow D, McClelland RA, Jones HE, Wakeling AE, Gee JMW: Modulation of epidermal growth factor receptor in endocrine-resistant, oestrogen receptor-positive breast cancer. Endocr Relat Cancer 2001, 8:175-182.

28. Morris C: The role of EGFR-directed therapy in the treatment of breast cancer. Breast Cancer Res Treat 2002, 75:S51-S55.

29. Arteaga C: Targeting HER1/EGFR: a molecular approach to cancer therapy. Semin Oncol 2003, 30 (3 Suppl 7):3-14.

30. Bianco R, Shin I, Ritter CA, Yakes FM, Basso A, Rosen N, Tsurutani J, Dennis PA, Mills GB, Arteaga CL: Loss of PTEN/MMAC1/ TEP in EGF receptor-expressing tumor cells counteracts the antitumor action of EGFR tyrosine kinase inhibitors. Oncogene 2003, 22:2812-2822.

31. Campiglio M, Locatelli A, Olgiati C, Normanno N, Somenzi G Vigano L, Fumagalli M, Menard S, Gianni L: Inhibition of proliferation and induction of apoptosis in breast cancer cells by the epidermal growth factor receptor (EGFR) tyrosine kinase inhibitor ZD1839 ('Iressa') is independent of EGFR expression level. J Cell Physio/ 2004, 198:259-268.

32. Gee JMW, Harper ME, Hutcheson IR, Madden TA, Barrow D, Knowlden JM, McClelland RA, Jordan N, Wakeling AE, Nichelson $\mathrm{RI}$ : The antiepidermal growth factor receptor agent gefitinib (ZD1839/Iressa) inproves antihormone response and prevents development of resistance in breast cancer in vitro. Endocrinology 2003, 144:5105-5117

33. Kris MG, Natale RB, Herbst RS, Lynch TJ, Prager D, Belani CP, Schiller JH, Kelly K, Spiridonidis H, Sandler A, et al:: Efficacy of gefitinib, an inhibitor of the epidermal growth factor receptor tyrosine kinase, in symptomatic patients with non-small cell lung cancer, a randomized trial. JAMA 2003, 290:2149-2158.

34. Fukuoka M, Yano S, Giaccone G, Tamura T, Nakagawa K, Douillard J-Y, Nishiwaki Y, Vansteenkiste J, Kudoh S, Rischin D, et al.: Multi-institutional randomized phase II trial of gefitinib for previously treated patients with adanced non-small-cell lung cancer. J Clin Oncol 2003, 21:2237-2246.

35. Cohen EEW, Rosen F, Stadler WM, Recant W, Stenson K, Huo D Vokes EE: Phase II trial of ZD1839 in recurrent or metastatic squamous cell carcinoma of the head and neck. $J$ Clin Oncol 2003, 21:1980-1987

36. Baselga J, Albanell J, Ruiz A, Lluch A, Gascon S, Guillen V, Sauleda S, Averbuch S, Rojo F: Phase II and tumor pharmacodynamic study of gefinitib (ZD 1839) in patients with advanced breast cancer [abstract]. Proc Am Soc Clin Oncol 2003, 22:S24.

37. Robertson JFR, Gutteridge E, Cheung KL, Owers R, Koehler M Hamilton L, Gee J, Nicholson Rl: Gefitinib (ZD 1839) is active in acquired tamoxifen (TAM)-resistant oestrogen receptor (ER)positive and ER-negative breast cancer: Results from a phase II study [abstract]. Proc Am Soc Clin Oncol 2003, 22:S23.

38. von Minckwitz G, Jonat W, Beckmann M, du Bois A, Kleeberg U, Kühnle H, Kettner E, Hilfrich J, Torode J, Schneider A: A multicenter phase II trial to evaluate gefitinib ('Iressa', ZD1839) (500 $\mathrm{mg} /$ day) in patients with metastatic breast cancer after previous chemotherapy treatment [abstract]. Proceedings of the 12th European Conference on Clinical Oncology, Copenhagen, Denmark . 21-25 sept. 2003, abstract 437

39. Giaccone G, Herbst RS, Manegold C, Scagliotti G, Rosell R, Miller V, Natale RB, Schiller JH, Von Pawel J, Pluzanska A, et al:: Gefitinib in combination with gemcitabine and cisplatin in advanced non-small-cell lung cancer: a phase III trial - INTACT 1. J Clin Oncol 2004, 22:777-784.

40. Herbst RS, Giaccone G, Schiller JH, Natale RB, Miller V, Manegold C, Scagliotti G, Rosell R, Oliff I, Reeves JA, et al.: Gefitinib in combination with paclitaxel and carboplatin in advanced nonsmall-cell lung cancer: a phase III trial - INTACT2. J Clin Oncol 2004, 22:785-794.

41. Pollak M: Insulin-like growth factor physiology and cancer risk Eur J Cancer 2000, 36:1224-1228.

42. Pollak M, Schernhammer ES, Hankinson SE: Insulin-like growth factors and neoplasia. Nat Rev Cancer 2004, 4:505-518.

43. Khandwala HM, McCutcheon IE, Flyvbjerg A, Friend KE: The effects of insulin-like growth factors on tumorigenesis and neoplastic growth. Endocr Rev 2000, 21:215-244.

44. $\mathrm{Yu} \mathrm{H}$, Rohan $\mathrm{T}$ : Role of the insulin-like growth factor family in cancer development and progression. J Natl Cancer Inst 2000, 92:1472-1489.

45. Wang $Y$, Sun $Y$ : Insulin-like growth factor receptor-1 as an anticancer target: blocking transformation and inducing apoptosis. Curr Cancer Drug Targets 2002, 2:191-207.

46. Werner $H$, LeRoith $D$ : The role of the insulin-like growth factor system in human cancer. Adv Cancer Res 1996, 68:183-223.

47. Dunn SE, Ehrlich M, Sharp NJ, Reiss K, Solomon G, Hawkins R Baserga R, Barrett JC: A dominant negative mutant of the insulin-like growth factor-I receptor inhibits the adhesion, invasion, and metastasis of breast cancer. Cancer Res 1998, 58:3353-3361. 
48. Wood TL, Yee D: Introduction: IGFs and IGFBPs in the normal mammary gland and in breast cancer. J Mammary Gland Biol Neoplasia 2000, 5:1-5.

49. Yee D: The insulin-like growth factor system as a target in breast cancer. Semin Oncol 2002, 29:86-95

50. Steinbach JP, Eisenmann C, Klumpp A, Weller M: Co-inhibition of epidermal growth factor receptor and type 1 insulin-like growth factor receptor synergistically sensitizes human malignant glioma cells to CD95L-induced apoptosis. Biochem Biophys Res Commun 2004, 321:524-530.

51. Parrizas M, Gazit A, Levitzki A, Wertheimer E, and LeRoith D: Specific inhibition of insulin-like growth factor-I and insulin receptor tyrosine kinase activity and biological function of tyrphostins. Endocrinology 1997, 138:1427-1433.

52. Hurbin A, Dubrez L, Coll JL, Favrot MC: Inhibition of apoptosis by amphiregulin via an insulin-like growth factor-1 receptordependent pathway in non-small cell lung cancer cell lines. $J$ Biol Chem 2002, 277:49127-49133.

53. von Willebrand M, Zacksenhaus E, Cheng E, Glazer P, Halaban R: The tyrphostin AG1024 accelerates the degradation of phosphorylated forms of retinoblastoma protein $(\mathrm{pRb})$ and restores pRb tumor suppressive function in melanoma cells. Cancer Res 2003, 63:1420-1429.

54. Wen B, Deutsch E, Marangoni E, Frascona V, Maggiorella L, Abdulkarim B, Chavaudra N, Bourhis J: Tyrphostin AG 1024 modulates radiosensitivity in human breast cancer cells. $\mathrm{Br} J$ Cancer 2001, 85:2017-2021.

55. Berenbaum MC: Criteria for analyzing inetactions between biologically active agents. Adv Cancer Res 1981, 35:269-335.

56. Busse D, Doughty RS, Ramsey TT, Russel WE, Price JO, Flanagan WM, Shawver LK, Arteaga CL: Reversible G(1) arrest induced by inhibition of the epidermal growth factor receptor tyrosine kinase requires up-regulation of p27(KIP1) independent of MAPK activity. J Biol Chem 2000, 275:6987-6995.

57. Sirotnak FM, Zakowski MF, Miller VA, Scher HI, Kris MG: Efficacy of cytotoxic agents against human tumor xenografts is markedly enhanced by coadministration of ZD1839 (Iressa), an inhibitor of EGFR tyrosine kinase. Clin Cancer Res 2000, 6:4885-4892.

58. Bailey LR, Janas M, Schmidt K, Bindslev N, Wolf M, Grous J, Askaa $J$, Herbst R, Johnson DH, Giacone G: Evaluation of epidermal growth factor receptor (EGFR) as a predictive marker in patients with non-small-cell lung cancer (NSCLC) receiving first-line gefitinib combined with platinum-based chemotherapy [abstract]. J Clin Oncol 2004, 22:S7013.

59. Arteaga C: Epidermal growth factor receptor dependence in human tumors: more than just expression? Oncologist 2002, 7:31-39.

60. Paez JG, Janne PA, Lee JC, Tracy S, Greulich H, Gabriel S, Herman $\mathrm{P}$, Kaye FJ, Lindeman N, Boggon TJ, et al.: EGFR mutations in lung cancer: correlation with clinical response to gefitinib therapy. Science 2004, 304:1497-1500.

61. Lynch TH, Bell DW, Sordella R, Gurubhagavatula S, Okimoto RA, Brannigan BW, Harris PL, Haserlat SM, Supko JG, Haluska FG, et al:: Activating mutations in the epidermal growth factor receptor underlying responsiveness of non-small-cell lung cancer to Gefitinib. N Engl J Med 2004, 350:2129-2139.

62. She QB, Solit D, Basso A, Moasser MM: Resistance to Gefitinib in PTEN-null HER-overexpressing tumor cells can be overcome through restoration of PTEN function or pharmacologic modulation of constitutive phosphatidylinositol 3'-kinase/Akt pathway signaling. Clinical Cancer Research 2003, 9:4340-4346.

63. Gilmore AP, Valentijn AJ, Wang P, Ranger AM, Bundred N, O'Hare MJ, Wakeling A, Korsmeyer SJ, Streuli CH: Activation of BAD by therapeutic inhibition of epidermal growth factor receptor and transactivation by isulin-like growth factor receptor. $J$ Biol Chem 2002, 277:27643-27650.

64. Maloney EK, McLaughlin JL, Dagdigian NE, Garrett LM, Connors KM, Zhou X-M, Blattler WA, Chittenden T, Singh R: An anti-insulin-like growth factor-I receptor antibody that is a potent inhibitor of cancer cell proliferation. Cancer Res 2003, 63:5073-5083.

65. Garcia-Echeverria C, Pearson MA, Marti A, Meyer T, Mestan J, Zimmermann J, Gao J, Brueggen J, Capraro H-G, Cozens R, Evans DB, Fabbro D, Furet $P$, Graus-Porta D, Liebetanz J, Martiny-Baron G, Ruetz S, Hofmann F: In vivo anti-tumor activity of NVP-
AEW541 - A novel, potent and selective inhibitor of the IGF-IR kinase. Cancer Cell 2004, 5:231-239.

66. Mitsiades CS, Mitsiades NS, McMullan CJ, Poulaki V, Shringarpure R, Akiyama M, Hideshima T, Chauhan D, Joseph M, Libermann $T A$, et al:: Inhibition of the insulin-like growth factor receptor-1 tyrosine kinase activity as a therapeutic strategy for multiple myeloma, other hematologic malignancies, and solid tumors. Cancer Cell 2004, 5:221-230.

67. Goetsch L, Gonzalez A, Leger O, Beck A, Pauwels PJ, Haeuw JF, Corvaia NA: A ecombinant humanized anti-insulin-like growth factor receptor type I antibody (h7C10) enhances the antitumor activity of vinorelbine and anti-epidermal growth factor receptor therapy against human cancer xenographs. Int J Cancer 2005, 113:316-328. 